\title{
International Journal of Multicultural
}

and Multireligious Understanding

\section{Legal Protection to the Holder of Freehold Estate Certificate for Land in Nagari Gadut of Agam Regency}

\author{
Gemala Giana, Kurnia Warman, Zefrizal Nurdin \\ Faculty of Law, Universitas Andalas Padang, Indonesia
}

http://dx.doi.org/10.18415/ijmmu.v6i2.733

\begin{abstract}
This research affirmed that at the end of 2013, the Indonesian Air Force claimed land located in Nagari Gadut, especially in the area of Jorong PSB (Pulai Sungai Talang Bukit Lurah) and Jorong PGRM (Pandam Gadang Ranggo Malai) as land owned by Indonesian Air Force. In fact, the local community already has a freehold estate certificate for the land. The problems in this research include: (1) how is the process of freehold estate registration in Nagari Gadut of Agam Regency claimed by the Indonesian Air Force? (2) What is the status of the community land in Nagari Gadut of Agam Regency after the claim from the Indonesian Air Force? (3) What is the legal protection for the holder of freehold estate certificate for land in Nagari Gadut of Agam Regency? This research applies an empirical juridical method and is included in descriptive analytical research. The data collection was carried out through document study and interview techniques. The data processing techniques included editing and coding. Based on the research results, it is concluded that: (1) In the process of registering land in the Japanese government's former booty area, the rights were derived through conversion. In general, the registration of land from which rights are derived through conversion is carried out through two stages, i.e. activities at the customary level and activities at the government level. (2) After the claims from Indonesian Air Force at the end of 2013, community's land in Nagari Gadut especially Jorong PSB and Jorong PGRM was in the status quo. (3) As long as there is no inkracht decision by the court, the land remains the property of the community. In addition, if the land is required by the Indonesian Air Force for public purposes, it can be resolved through a land acquisition mechanism.
\end{abstract}

Keywords: Legal Protection; Freehold Estate Certificate; Indonesian Air Force

\section{Introduction}

Land is a source of welfare and prosperity of the people as stated in Article 33 paragraph (3) of the 1945 Constitution (Purnomo \& Anand, 2014). Community, who has had a freehold estate certificate for land, has been guaranteed and protected by law for their ownership of the land. However, in some cases, there are still people who have not received legal certainty over the land they own; for instance, legal certainty for the freehold estate certificate for land owned by the Nagari Gadut people of Agam Regency, especially those living in Jorong Pulai Sungai Talang Bukit Lurah (PSB) and Jorong Pandam Gadang Ranggo Malai (PGRM) (Ariatama, 2016). 
At the end of 2013, the people of Nagari Gadut, who administered land administration such as the making of a freehold estate certificate for land, transferring the title of the certificate, and splitting the certificate, were unable to administer land administration at the Agam Regency Land Office (Mirwati et $a l ., 2017)$. It was caused by claims from the Indonesian Air Force which stated that the land owned by the community was state land controlled by the Indonesian Air Force. The claim from the Indonesian Air Force caused the suspension of land administration submitted by the community to the Agam Regency Land Office.

Agam Regency Land Office stated that the land was in the process of State Wealth Inventory, which was controlled by Indonesian Air Force; therefore, the freehold estate certificate, certificate splitting, or title transfer that is processed by the community cannot be issued because the land status is unclear. In fact, in previous years, the Agam Regency Land Office had issued freehold certificates to people who own land in the area. There are approximately 1657 certificates issued by the Agam Regency Land Office.

The Command Letter of Air Force Operation 1 of the Indonesian Air Force Base Padang, addressed to the Head of Agam Regency Land Office Number B/02/I/2014 dated January 3, 2014 concerning the status of Gadut land signed by Handaka, S. Sos, MM, stated that the basis for Indonesian Air Force to claim the land is a guideline for the Government Accounting Standards Committee No. 023/P/KSAP/50 dated May 25, 1950 which decided that all airports, buildings, and equipment located in the field belong to Indonesian Air Force, Circular Letter of the Minister of Home Affairs No. H.20/5/7 dated May 9, 1950 concerning Settlement of Land Formerly Taken by the Japanese Government, and Circular Letter of the Minister of Home Affairs No. Agr.40/25/13 dated May 13, 1953 concerning Settlement of Land Formerly Taken by the Japanese Government and the Deadline for Settlement of Land Issues until the end of 1953.

Historically, the land claimed by the Indonesian Air Force was formerly communal land. The community's control of the land has been going on for a long time and has passed down long before the arrival of the Dutch colonizers to Indonesia. In the colonial era of the Dutch East Indies Government, they had planned to build airport above ground to the Ambacang Hill area of Bukittinggi City. However, before that was realized, the occupation of the Dutch East Indies Government in Indonesia had ended because Dutch had handed over its power to the Japanese Government.

The handover of sovereignty by Lieutenant General H. Ter Poorten, as Commander of the Dutch East Indies Armed Forces to the Japanese Armed Forces under the leadership of Lieutenant General Hitosyi Imamura on 8 March 1942 in Kalijati, marked the end of the Dutch East Indies government power and was replaced by power Japanese government. Unlike the Dutch era which was a civil government, the government in the Japanese era was a military government. ${ }^{1}$

The Japanese government came to Nagari Gadut in late 1942 which at that time coincided with the outbreak of the Greater East Asia War. To maintain its power in Indonesia, the Japanese Government built fortifications to anticipate attacks from the enemy. One of them is to build an airport using the lands of customary people. Based on maps circulating in the community, the land used for the construction of the airport is 287,600 ha; however, this map cannot be used as a benchmark because the source is unclear. The amount of land claimed by the Indonesian Air Force on the Japanese government's former booty land is $287,600 \mathrm{Ha}$ which is exactly the same as the map circulating among the people. In fact, the land has now been controlled by the community and the community has a freehold estate certificate for the land.

After Indonesian independence in 1945, the former airport built by the Japanese Government were taken over by the Indonesian Air Force. Indonesian Air Force controlled the airport from 19451948. During this period, there were no infrastructures to support the smooth flight in the field built by the Indonesian Air Force. The mess hall for members of the Indonesian Air Force utilized public

\footnotetext{
${ }^{1}$ Ilham Irhas, History of Japanese Occupation in Indonesia, www.materi-sma.com, downloaded on April 25, 2014, at 09:07 West Indonesia Time.
} 
infrastructure; i.e. the elementary school that was previously used by the Dai Nippon army so that it made the Elementary School to be transferred to the Aro Kandikia area.

Starting from 2013 until now, this problem has not found the best solution. Agam Regency Land Office still suspends land administration submitted by the community. In fact, the community has a freehold estate certificate for the land that legally provides legal certainty and protection.

Freehold estate is a basic right for every citizen guaranteed by the constitution. Therefore, the legal certainty of land ownership is an essential requirement. The issuance of freehold estate certificate for land, as proof of freehold estate for ownership of land, should provide peace to the rights holders from the interference of other parties.

\section{Research Method}

\section{Research Design}

The writing of this legal research applies the research design in the form of legal juridical empirical writing; i.e. the problem approach through legal research by looking at the applicable legal norms (Marzuki, 2017). It connects with the facts that exist in the community regarding the problems encountered in the research (Yusuf, 2016). The data analysis carried out in this research is qualitative analysis (Irianto, 2009). It means that the data collected is not in the form of numbers so that it does not use statistical formulas for the analysis process. The analysis is in the form of sentence descriptions.

\section{Findings and Discussion}

\section{Registration Process of Freehold Estate for Land in the Japanese Government's Former Booty Area in Nagari Gadut of Agam Regency}

Historically, the land claimed by the Indonesian Air Force at the beginning was communal land belonging to customary law community. After the Japanese Government surrendered to the allies in 1945 and Indonesia declared its independence, the land taken by the Japanese Government to build the airport was again controlled by the customary law community. The customary community physically has controlled the land for decades without interference from other parties.

Article 3 of the Basic Agrarian Law recognizes the existence of customary rights insofar as they exist and do not conflict with national and state interests. Therefore, the customary law community registered the Japanese government's former land through the conversion method. As described in the literature review in Chapter II, conversion is a change in old rights into rights that are in accordance with what is regulated by the Basic Agrarian Law.

Based on Minister of Agriculture and Agrarian Regulation No. 2 of 1962 concerning the Affirmation of the Conversion and Registration of Former Indonesian Rights on Land connected with Decree of the Minister of Home Affairs No. SK 26/DDA/1970 concerning the Affirmation of the Conversion and Registration of Former Indonesian Rights on Land, that lands which have tax letters on land or Indonesian verponding land issued before September 24, 1960, can be considered as proof of the right to be converted into a freehold estate.

Furthermore, based on Article 3 of the Minister of Agriculture and Agrarian Regulation No. 2 of 1962 concerning the Affirmation of the Conversion and Registration of Former Indonesian Rights on Land, applications for confirmation of the conversion of former customary land must be accompanied by a proof of rights (Lucas \& Warren, 2003). The proof of rights referred to consists of:

a. "A letter of proof of Indonesian tax/verponding or a proof of entitlement by the competent authority (also included the measurement letter if any)

b. Letter of Statement from the Village Head confirmed by the District Head, who: 
1) Justify the letter or proof of rights

2) Explain whether the land is residential land or agricultural land

3) Explain who has the right, accompanied by derivative letters of sale and purchase of land if any.

c. Proof of legal citizenship from those who have the rights."

According to the provisions of Article 3, specifically for lands subject to Customary Law, but not registered in the provisions of conversion as land which can be converted to land rights according to the provisions of the Basic Agrarian Law, it is still recognized as customary rights. Therefore, it is pursued by the effort of "Confirmation of Rights" submitted to the Head of the local Land Office accompanied by preliminary evidence such as tax proof, sale and purchase letter made before the enactment of the Agrarian Basic Law and a letter confirming the rights of someone and explaining also whether the land is for housing and for agriculture and citizenship information of the person concerned.

Based on the above rules, one of the customary law communities that applied for a land registration application named Sainam submitted an application by completing the following conditions:

a. Proof of tax on agricultural products

b. Letter from the Village Head of Nagari who justifies the proof of rights that is confirmed by the District Head

c. Letter that the land is not in dispute

d. Proof of citizenship

e. Ranji (lineage list)

f. Statement of land tenure

Based on the application, Agam Regency Land Office measured the land applied by Sainam on December 1, 1992, No. 799/1993, with a land area of 2,490 $\mathrm{m}^{2}$. After going through the process of measurement and announcement, on April 26, 1993, the certificate in the name of Sainam had been issued with the status of freehold estate from which the ownership originated from the conversion of customary freehold estate land. The administrative cost incurred by Sainam in the land registration process is IDR 1500 .

Based on the results of interviews with Glanovix Adryzeb, Head of the Disputed Sub-Section of Agam Regency Land Office, from the initial registration of the Japanese's former booty land, there are 1657 certificates issued by the Agam Regency Land Office with details as follows: 1657 registered certificates as freehold estate , 91 right of building certificates, and 3 right of use certificates. ${ }^{3}$

Based on the Circular Letter of the Agrarian Directorate of West Sumatra Province Number DA6980/III2F/1983 concerning the orderly procedure for resolving application for confirmation of rights to land originating from customary land, it is carried out with the following conditions:

a. Every settlement of an application for affirmation of rights to land originating from customary land must be through the procedure as referred to in Domestic Investment No. 5 of 1973 jo. Minister of Agriculture and Agrarian Regulation No. 2 of 1962.

b. The materials for proof of ownership/control of the land are in the form of:

1) A statement of land ownership from the concerned which is strengthened by the District Head.

2) Letter from the Village Head/Lurah that is confirmed by the District Head.

\footnotetext{
${ }^{2}$ Muchtar Wahid, Op. Cit., page 28.

${ }^{3}$ Interview with Glanovix Adryzeb Head of Dispute Sub Section of Agam Regency Land Office, on November 27, 2018, at 10:00 West Indonesia Time.
} 
3) Other evidence such as buying and selling letters, grants that existed before Government Regulation No. 10 of 1961, and so forth, all of which are confirmed by the District Head.

4) For clan land, it is necessary to attach ranji (lineage list) of the concerned people made by mamak kepala waris (the head of the inheritance) and confirmed by the respective tribal leaders and local government officials whose declaration of ownership must include the names of members of the rightful people who are adults (17 years and above) at the time the statement is made. A statement of land ownership and certificates from the original government official is stored at the local government office to be integrated with the land certificate; whereas, the duplicate is sent as an attachment to the application in question.

Parties who must know and approve by signing the statement of ownership are: (1) the party concerned, (2) heirs, (3) mamak kepala waris (the head of the inheritance) and chief of tribe, (4) sepadan (owner of adjacent land), (5) the local government, village head/lurah and district head, (6) Customary Nagari Institution, etc. as long as needed.

c. The proof documents are used as material for examination by Committee A.

d. The results of the examination by Committee A must be announced with the use of places that have been determined through officials as below:

1) By the local district head on the noticeboard for two months.

2) By the village head/lurah on the noticeboard for two months.

3) By the administrator of the mosque where the land is located which is announced for three consecutive Friday sessions.

After the grace period has passed, the officials mentioned above submit the results of the announcement to the land office accompanied by a statement about whether there are parties who object to the announcement.

e. After all documents for the application are complete and there is no claim from another party and the grace period has been exceeded, the application file is forwarded by the Land Office to the Regional Office of the National Land Agency of West Sumatra Province for further processing.

f. If, according to the assessment of the Regional Office of the National Land Agency, the application is feasible to be issued, then a decision regarding the affirmation of rights on behalf of the applicant will be issued.

The final product of the Japanese Government's former booty communal land registration activity is a certificate of land rights. If the certificate, as proof of ownership of a plot of land, is obtained in good faith, then it is considered legitimate and becomes a strong evidence tool.

2. Suspension of Land Administration/Block Registration at the Japanese Government's Former Confiscation Area in Nagari Gadut of Agam Regency

At the end of 2013, the claim from the Indonesian Air Force, which stated that the Japanese government's former booty land was the land of the Indonesian Air Force, caused public unrest. This claim from the Indonesian Air Force has caused land in the $287.6 \mathrm{Ha}$ of the Japanese government's former booty land to be in the status quo. Until now the community physically still controls the land but cannot carry out legal actions against land rights such as the transfer of rights, mortgage rights, etc.

In the letter, the basis used by the Indonesian Air Force to claim that the land belongs to the Indonesian Air Force is guided by:

a. Government Accounting Standards Committee No. 023/P/KSAP/50 dated May 25, 1950 which decided that all airports, buildings, and equipment located in the field belong to Indonesian Air Force. 
b. Circular Letter of the Minister of Home Affairs No. H.20/5/7 dated May 9, 1950 concerning Settlement of Land Formerly Taken by the Japanese Government.

c. Circular Letter of the Minister of Home Affairs No. Agr.40/25/13 dated May 13, 1953 concerning Settlement of Land Formerly Taken by the Japanese Government and the Deadline for Settlement of Land Issues until the end of 1953.

One of the legal bases of the Indonesian Air Force claims that the land belongs to the Indonesian Air Force is the Circular Letter of the Minister of Home Affairs No. H.20/5/7 dated May 9, 1950 concerning Settlement of Land Formerly Taken by the Japanese Government, which among others regulates as follows:

a. "Land taken and handed over with fear and coercion can be returned to the owner or his/her heir with a refund of the money already paid by recalculating using a sliding scale.

b. If the person concerned does not want the land to return, then the recalculation can be carried out.

c. Customary land that has been paid is deemed to have been released with these payments and becomes free state land.

d. If it is taken without payment, the land remains the property of the person concerned.

e. Regarding the lands of western rights that are taken because they were not taken through the procedure of rights revocation, the land is still registered in the name of the person concerned.

f. If the land previously had buildings and trees, a refund must be made only partially if the buildings no longer exist."

Based on the points in the Circular Letter of the Minister of Home Affairs above, as stated in point a, it is stated that community communal lands submitted to the Japanese Government with fear and coercion can be returned to their owners or heirs with refunds of money already paid calculated based on the sliding scale. Thus, some people who at that time received compensation for plants growing on the land could return the money received from the Japanese Government to the state. However, for some people whose land was taken forcibly, the land returned to its owner; in this case the customary law community. Submission of land with fear and coercion cannot be justified by law, because this is an act of abuse and an act of seizing the rights of others.

Point c states that the customary land that has been paid is deemed to have been released with the payment and becomes free state land. Based on the information above, the Japanese Government's former booty land in Nagari Gadut will change its status to state land if the community has received compensation for customary land. However, in reality, the community only receives compensation for plants that grow on the land. In fact, some people do not receive compensation at all. Thus, the Japanese Government's former booty land is still recognized as communal land of customary law community and not as free state land. Since regaining the control of former airport land in the 1950s by the customary law community, the Agam Regency Government has not made any effort to control or take over the land, so that the customary law community can process, utilize, and control the land without interference from other parties.

Based on the Regulation of the Minister of Agrarian and Spatial Planning/ Head of the National Land Agency of the Republic of Indonesia No. 16 of 2016 concerning Land Settlement, hereinafter referred to as the Regulation of the Minister of Agrarian and Spatial Planning No. 16 of 2016, the settlement of land cases is divided into two. First, settlement of land cases is the authority of the ministry; in this case the National Land Agency. Secondly, the settlement of land cases is not the authority of the ministry.

\footnotetext{
${ }^{4}$ A.P Parlindungan, Registration and Conversion of Land Rights According to the Agrarian Basic Law, Bandung: Alumni, 1988, page 12.
} 
Article 11 paragraph (3) Regulation of the Minister of Agrarian and Spatial Planning No. 16 of 2016 states that land cases that are the authority of the ministry include:

a. procedural error in the process of measuring, mapping and/or calculating land area

b. procedural error in the registration, affirmation, and/or recognition process of rights to former customary land

c. procedural error in the process of determining and/or registering land rights

d. procedural error in the abandoned land assignment process

e. overlapping rights or certificates of land rights where one of the rights is clearly wrong

f. procedural error in the process of maintaining land registration data

g. procedural error in the issuance process of replacement certificate

h. error in providing information on land data

i. procedural error in the permit process

j. misuse of space use, or

k. other errors in the application of legislation.

In addition to land cases stipulated in Article 11 paragraph (3) the Regulation of the Minister of Agrarian and Spatial Planning No. 11 of 2016 above, the settlement of the land case is the authority of other agencies and is not the authority of the ministry (National Land Agency).

Land cases which are the authority of the ministry generally are related to administrative error and procedure in issuing the certificate. Regarding the dispute that took place between the holder of the freehold estate for land in the Japanese's former booty area in Nagari Gadut and the Indonesian Air Force, the settlement is not the authority of the National Land Agency.

Based on the letter sent by the Indonesian Air Force, the Agam Regency Land Office has sent a letter to the West Sumatra Provincial Land Office regarding the application for instructions on land cases in Nagari Gadut of Agam Regency. To follow up on the letter, the West Sumatra Province Regional Office sent a letter to the Ministry of Agrarian and Spatial Planning/ National Land Agency regarding the application for land case instructions in Nagari Gadut of Agam Regency. Until now, land cases in Nagari Gadut are still in the process of being resolved at the ministry level. Thus, there has been no reply from the ministry regarding the settlement of the land case. ${ }^{5}$

Blocking record is administrative action of the Head of the Land Office or designated official to establish the status quo (suspension) of temporary land rights against legal suspension and legal events on the land. What is meant by the status quo is a fixed condition as what the current condition is.

In Article 3 of the Regulation of the Minister of Agrarian and Spatial Planning/ Head of the National Land Agency of the Republic of Indonesia No. 13 of 2017 concerning the Blocking Procedure, hereinafter referred to as the Regulation of the Minister of Agrarian and Spatial Planning No. 13 of 2107, registration of blocking is carried out on land rights over legal actions or legal events, or because of land disputes or conflicts. Land book that has blocking record cannot carry out maintenance of land registration data.

Application for blocking record can be submitted by:
a. Individual
b. Legal entity
c. Legal apparatus

\footnotetext{
5 Interview with Glanovix Adryzeb Head of Dispute Sub Section of Agam Regency Land Office, on November 27, 2018, at 10:00 West Indonesia Time.
} 
Application for blocking record must include clear reasons and the applicant must be willing to go through the examination regarding the application. This is regulated in Article 4 of the Regulation of the Minister of Agrarian and Spatial Planning No. 13 of 2017. Individuals or legal entities that submit applications for blocking record must have a legal relationship with the land being applied for. Applicants, who have a legal relationship with the land referred to as stipulated in Article 5 of the Regulation of the Minister of Agrarian and Spatial Planning No. 13 of 2017, consist of:

a. Landowner; individual or legal entity

b. Parties to the agreement; notarial or private or community property ownership not in marriage

c. Heirs or community property ownership in marriage

d. Agreement maker; notarial or private based on power, or

e. Bank mentioned in the notarial deed of the parties.

Conditions for blocking application by individual or legal entity include:

a. Application form containing a statement regarding the agreement that blocking record is null if the time period has expired

b. Copy of the applicant's identity or proxy, and the original copy of Power of Attorney if it is authorized

c. Copy of the Law Establishment Deed

d. Information about the name of the rights holder, type of rights, number, area, and location of land to be applied for blocking

e. Proof of deposit of state revenues; not the tax regarding blocking record

f. Proof of legal relationship between the applicant and the land, such as:

1) Claim and case register number or suspension by the State Administrative Court in the right for blocking application accompanied by a lawsuit in court

2) Marriage certificate/ marriage book, family card, or Court Decision relating with divorce or statement of inheritance, in the case of blocking application for community property disputes in marriage and/or inheritance, and

3) Court decisions relating to accounts payable or deed of sale and purchase agreement, lending and borrowing, exchange certificates which have been legalized by an authorized official, in the case of a blocking application for legal action.

Regarding claim by the Indonesian Air Force, land in the Japanese Government's former booty area of 287.6 hectares is in the status quo. Until now, the community physically still controls the land but cannot carry out legal actions against land rights such as the transfer of rights, mortgage rights, etc.

\section{Legal Protection Against the Holder of Freehold Estate Certificate for Land in the Japanese Government's Former Booty Area in Nagari Gadut of Agam Regency}

As a legal guarantee given by the government on land, the government provides a proof of title called a certificate and applies as a strong evidence tool. It means that the information contained in it has legal force and must be accepted by the judge as correct information as long as there is no other means of proof that proves otherwise.

In the section on the process of freehold estate land registration in the Japanese Government's former booty area, the community has registered its land through conversion rights; therefore, the community has a certificate of right in the form of a certificate. The process of issuing the freehold estate land certificate has been through procedures that have been established by the Agam District Land Office. Thus, the certificate is valid and serves as a strong evidence tool. However, the claim from the Indonesian 
Air Force, which states that the land in the Japanese Government's former booty area belongs to the Indonesian Air Force, has caused unrest for the people.

So far, the Agam Regency Land Office has issued a freehold estate certificate to the public. Normatively, Article 56 of the Basic Agrarian Law mandates the search for a history of land ownership through a cultural legal approach to overcome weaknesses in the lack of formal evidence contained in the customary law system. The mechanism to arrive at the certificate issuance stage certainly requires time, process, and requirements so that the authorities are sure of the truth of the data.

The basis of Indonesian Air Force claims that the land belongs to Indonesian Air Force is guided by the Government Accounting Standards Committee No. 023/P/KSAP/50 dated May 25, 1950 which decided that all airports, buildings, and equipment located in the field belong to Indonesian Air Force, Circular Letter of the Minister of Home Affairs No. H.20/5/7 dated May 9, 1950 concerning Settlement of Land Formerly Taken by the Japanese Government, and Circular Letter of the Minister of Home Affairs No. Agr.40/25/13 dated May 13, 1953 concerning Settlement of Land Formerly Taken by the Japanese Government and the Deadline for Settlement of Land Issues until the end of 1953.

Claim from Indonesian Air Force based on Circular Letter of the Minister of Home Affairs No. The H.20/5/7 cannot be used as a basis for land ownership by the Indonesian Air Force, because there is not a single provision in the circular letter stating that the Japanese Government's former booty land belongs to the Indonesian Air Force. If the Indonesian Air Force bases the claim based on the letter c in the Circular Letter of the Minister of Home Affairs stating that "customary land that has been paid is deemed to have been released with the payment and becomes free state land", it must be proven and accounted for by the party Indonesian Air Force. In this case, the Indonesian Air Force must prove whether the community has received compensation for communal lands which were previously seized by Japan.

Based on the results of interviews with one of the leaders of Nagari Gadut, Datuak Bagindo, the community only receives compensation for plants that grow on the former land of the airport where the amount of money that the community received was not comparable and in accordance with the appropriate price. In addition, the condition of the Japanese Occupation Government which at that time was facing the Greater East Asia War was not possible to provide compensation for communal land. The need for weapons and so on required the Japanese Government's finance to prioritize more the military purposes; in this case, for the benefit of the Japanese Occupation Government itself in order to maintain its power in Indonesia from allied countries. ${ }^{6}$

Claim from the Indonesian Air Force on the Japanese Government's former booty land emerged in August 2013 along with the emergence of a growing issue in the community that there would be a pioneering airport on the land by the Agam Regency Government. As what has been explained in the first sub-section, the status of the Japanese Government's former booty land is not state land but communal land of the customary law community which at this time has been converted by customary community into a freehold estate whose land comes from communal land. Physically, the community has also controlled the land for decades since 1950 until now. If indeed the Japanese Government's former booty land is really needed for the construction of a pioneer airport that will provide benefits to the community and the public interest, the government can conduct land acquisition.

If the issue that develops in the midst of the community comes from an accountable source, related to the right to control the state then based on Article 2 paragraph (2) of the Basic Agrarian Law, the state has the authority to:

a. "Regulate and organize the designation, use, supply and maintenance of earth, water and space,

b. Determine and regulate legal relationship between people and earth, water and space, and

\footnotetext{
${ }^{6}$ Interview with the figure of Nagari Gadut, Datuak Bagindo, on October 15, 2018, at 14.00 West Indonesia Time.
} 
c. Determine and regulate legal relationship between people with legal actions regarding earth, water and space."

In relation to land issues, the nature of the state's right to control the land is to build, cultivate, maintain and regulate land for the interests of the state, the public interest, the common interests of the people and to help individual interests. The state, in this case, is not the owner of the land. The state is only the highest organization that regulates land.

Legal protection for the community whose land is taken for public interest which formally has been included in the laws and regulations needs to be consistently realized. The right of the state is to take the land of rights for the public interest as a whole; however, respect for basic human rights should be given proportionally. Since the state has a role as an actor, the state has an equal position with the rights holders and thus must also submit to the rules/ provisions made by itself. Apart from this matter, the state acts as a regulator of existing conflict of interest. If a conflict of interest occurs, the state is expected to be a fair referee (Sumardjono, 1989).

Based on some expert opinions on the theory of legal protection, Fitzgerald and Phillipus M. Hadjon, which have been described in the theoretical framework in Chapter I, legal protection is the realization of the functioning of the law given to legal subjects to realize legal objectives; i.e. justice, legal certainty, and expediency. The community that already has a freehold estate certificate for land in the Japanese Government's former booty area has not yet obtained legal certainty over their lands. The form of repressive government legal protection in resolving disputes has not gone massively. It is because since this dispute emerged at the end of 2013, it has not found the best solution until now.

Therefore, the legal protection for the holders of the freehold estate certificate in the Japanese Government's former booty area is still weak. Freehold estate as the strongest right to land owned by the community cannot work properly. People cannot transfer land rights or conduct legal actions to the land because it is still in the status quo. This problem is also protracted because the Indonesian Air Force, which feels entitled to the land, did not file a lawsuit to the court so that there is no legal certainty over the status of the land until now.

\section{Conclusion}

Based on the descriptions that have been stated in the previous chapters and based on the results of the research and discussion of the data on the problems raised, the following conclusions can be drawn:

Land registration on the Japanese Government's former booty area in Nagari Gadut was carried out through the conversion method. According to Article 3 of the Minister of Agriculture and Agrarian Regulation No. 2 of 1962 concerning the Affirmation of the Conversion and Registration of Former Indonesian Rights on Land, application for confirmation of the conversion of former customary land must be accompanied by a proof of rights. Based on this article, the customary law community who will register their land, submit an application to the Agam Regency Land Office by completing the following conditions: proof of tax on agricultural products, letter from the Village Head of Nagari who justifies the proof of rights that is confirmed by the District Head, letter that the land is not in dispute, proof of citizenship, ranji (lineage list), and a statement of of land tenure. After submitting an application, the next stage is measuring land parcels, announcements, and issuing certificates of land rights. The Nagari Gadut community that registers its land has gone through a process that has been determined by the prevailing regulations so that the certificate issued by the Agam Regency Land Office is legal and serves as a strong evidence.

The claim from the Indonesian Air Force, against community land in the Japanese Government's former booty area through the Command Letter of Air Force Operation 1 of the Indonesian Air Force Base Padang, addressed to the Head of Agam Regency Land Office Number B/02/I/2014, has made the community land in the Japanese Government's former booty area is in the status quo. Until now, the dispute between the community and the Indonesian Air Force has not reached the stage of the case in court. The Indonesian Air Force as a party that feels entitled to the land does not file a claim to the court. 
Certificates that the community has are legitimate which should provide legal certainty and legal protection for the owner.

The community has had a freehold estate certificate for land in the Japanese Government's former booty area in good faith and through the established mechanisms and procedures. Thus, the certificates that the community has are legal and can function as a strong evidence. Claim from the Indonesian Air Force which state that the land belongs to the Indonesian Air Force, in this case the Indonesian Air Force must prove it. Since the emergence of claim from the Indonesian Air Force from the end of 2013 to the present, no one from the Gadut community or the Indonesian Air Force has filed a lawsuit to the Court. Thus, if there is no inkracht decision from the court, the land remains the property of the community. If community land is needed by the Indonesian Air Force for public purposes, the government can carry out a land acquisition mechanism.

\section{References}

\section{Books}

Irianto, S. (Ed.). (2009). Metode Peneltian Hukum: Konstelasi dan Refleksi. Yayasan Pustaka Obor Indonesia.

Marzuki, M. (2017). Penelitian Hukum: Edisi Revisi. Prenada Media.

Purnomo, E. P., \& Anand, P. B. (2014). Similarity index: The Conflict of Forest Tenure and the Emergence of Community Based Forest Management in Indonesia.

Sumardjono, M. S. (1989). Pedoman Pembuatan Usulan Penelitian. Universitas Gajah Mada, Yogyakarta.

Yusuf, A. M. (2016). Metode penelitian kuantitatif, kualitatif \& penelitian gabungan. Prenada Media.

\section{Journals}

Ariatama, R. (2016). Relasi Kuasa Nagari Dengan Pemerintah Daerah Kabupaten: Studi Kasus Relasi Kuasa Nagari Gadut dengan Kabupaten Agam tahun 1999-2014(Doctoral dissertation, Universitas Gadjah Mada).

Mirwati, Y., Oktarina, N., \& Kamisli, S. (2017). Legal Certainty of Ulayat Landscertification in the Empowerment of Nagari Assets in West Sumatera Province. International Journal, 2(6), 127-138.

Lucas, A., \& Warren, C. (2003). The state, the people, and their mediators: the struggle over agrarian law reform in post-New Order Indonesia. Indonesia, (76), 87-126.

\section{Legislation}

Undang-Undang Dasar Tahun 1945 
Undang-undang No. 5 Tahun 1960 Tentang Peraturan Dasar Pokok-pokok Agraria

Peraturan Pemerintah No. 24 Tahun 1997 Tentang Pendaftaran Tanah

Peraturan Mentri Agraria No. 3 Tahun 1997 Tentang Ketentuan Pelaksanaan Peraturan Pemerintah No. 24 Tahun 1997 Tentang Pendaftaran Tanah

Peraturan Menteri Pertanian dan Agraria No. 2 Tahun 1962 Tentang Penegasan Konversi dan Pendaftaran Bekas Hak Indonesia Atas Tanah

Surat Keputusan Menteri Dalam Negeri No. SK 26/DDA/1970 Tentang Penegasan Konversi dan Pendaftaran Bekas Hak-hak Indonesia Atas Tanah

Surat Edaran Direktorat Agraria Propinsi Sumatra Barat Nomor DA-6980/III2F/1983 perihal tertib prosedur penyelesaian permohonan penegasan hak atas tanah yang berasal dari tanah adat

\section{Website}

www.harianhaluan.com

Badan Pertanahan Nasional, Jurnal Pertanahan, http://perpustakaan.bpn.go.id.elibrary/digital\%20Documents/Koleksi_5757.pdf,

\section{Copyrights}

Copyright for this article is retained by the author(s), with first publication rights granted to the journal. This is an open-access article distributed under the terms and conditions of the Creative Commons Attribution license (http://creativecommons.org/licenses/by/4.0/). 